\title{
Differences in juvenile trophic niche for two coastal fish species that use marine and estuarine nursery habitats
}

\author{
Ryan J. Woodland ${ }^{1,2, *}$, David H. Secor ${ }^{1}$ \\ ${ }^{1}$ Chesapeake Biological Laboratory, University of Maryland Center for Environmental Science, Solomons, Maryland 20688, USA \\ ${ }^{2}$ Present address: Water Studies Centre, Department of Chemistry, Monash University, Clayton, Victoria 3800, Australia
}

\begin{abstract}
In coastal regions, age-0 juveniles of many fish species are capable of recruiting to either marine or estuarine nursery habitats, yet the ecological consequences for cohorts that use marine versus estuarine nurseries is poorly understood. In the present study, stable isotope $\left(\delta^{13} \mathrm{C}\right.$, $\delta^{15} \mathrm{~N}$ ) and stomach contents data were used to compare trophic ecology associated with differential habitat use for age-0 bluefish Pomatomus saltatrix and bay anchovy Anchoa mitchilli from 2 habitats: Maryland's (USA) inner continental shelf (shelf) and lower Chesapeake Bay (estuary). Bluefish occupied equivalent trophic positions (approx. 4.0 to $4.2 ; \delta^{15} \mathrm{~N}$ - and diet-based estimates) as tertiary consumers in the shelf and estuary. In contrast, bay anchovy were secondary-tertiary consumers with trophic position estimates of 3.5 to 3.8 in the shelf and 3.5 in the estuary. A C:N ratio proxy for lipid content was higher in the shelf cohorts for both species, and weight-at-length was also higher for shelf bay anchovy than estuarine bay anchovy. Estuarine cohorts of both species occupied a larger isotopic niche (i.e. convex hull area), yet 2-source mixing model results indicated that estuarine cohorts derived $>80 \%$ of their biomass from pelagic food webs alone. Conversely, shelf cohorts more equitably integrated pelagic (bluefish: $45 \pm 7 \%$ [SD], bay anchovy: $46 \pm$ $12 \%$ ) and benthic food webs. The present study indicates that the juvenile trophic niche of these species can vary significantly across habitats and provides initial evidence that cohorts recruiting to Maryland's shelf can realize more diverse (i.e. utilization of multiple food webs) or superior (i.e. increased condition - bay anchovy only) foraging conditions than cohorts recruiting to proximal estuaries.
\end{abstract}

KEY WORDS: Nursery habitat $\cdot$ Estuarine dependence $\cdot$ Condition $\cdot$ Stable isotope $\cdot \mathrm{C}: \mathrm{N}$ ratio • Stomach contents

Resale or republication not permitted without written consent of the publisher

\section{INTRODUCTION}

The survival, growth, and eventual recruitment of juvenile marine fish to adult populations depends on favorable nursery conditions. Exposure to unique combinations of biotic and abiotic factors in different nursery habitats, often mediated through parental reproductive strategies (e.g. spatial and temporal bet hedging; Secor 2007), is an important determinant of spatial patterns in juvenile production (Beck et al. 2001). Quantifying juvenile production from individual habitats is important for understanding recruitment and population dynamics and developing coastal-habitat management strategies (e.g. prioritization of conservation effort; Beck et al. 2001, Kraus \& Secor 2005, Dahlgren et al. 2006). However, without an understanding of the ecological mechanisms that support habitat-specific production and condition of juvenile recruits, knowledge of spatial production patterns alone are insufficient for holistic, 
spatially explicit decision-making (Sheaves et al. 2006). For example, if a particular habitat supports a high population of juveniles due to the presence of an abundant forage base, protection of the juveniles alone would not be sufficient to maintain juvenile production - the forage base would also need to be protected.

One critical component of juvenile habitat quality is an accessible forage base that supports basal metabolic processes while allowing positive somatic growth and energy storage (e.g. Gibson 1994, Nislow et al. 2000, Rosenfeld et al. 2005). Among conspecifics, an individual's realized trophic niche can vary between habitats depending on the composition of local prey fields, presence of physical habitat (e.g. seagrasses, oyster reefs), physicochemical conditions, anthropogenic effects, and density-dependent effects (Gerking 1994). By influencing growth rate and the duration of size-dependent predation vulnerabilities, spatial variability in realized trophic niche can influence early survivorship patterns (Werner \& Gilliam 1984), thereby linking intra-cohort foraging dynamics to recruitment success and population persistence. Energy-storage dynamics during the juvenile phase may be particularly important for species inhabiting temperate coastal ecosystems that require sufficient energy reserves to sustain recruits during seasonal migrations and/or overwintering periods (Schultz \& Conover 1997).

Metrics that assess realized trophic niche are either based on direct observations of food habits such as quantification of stomach contents (e.g. Scharf et al. 2000) or indicators of time-integrated foraging history such as stable isotope ratios or fatty acid composition (Graeve et al. 1997, Bearhop et al. 2004). For the latter group of niche metrics, representations include trophic niche width and variability ranging from the individual to the community level (Bearhop et al. 2004, Layman et al. 2007). By integrating assimilated nutrient characteristics over a period of weeks to months, stable isotope-based approaches can provide a holistic representation of trophic ecology throughout the nursery residence period (Herzka 2005).

In the present study, we conducted a comparative analysis of ecological and physiological consequences arising from the use of different juvenile habitats by age-0 bluefish Pomatomus saltatrix and bay anchovy Anchoa mitchilli. Substantial research exists on the population dynamics and trophic ecology of juvenile bluefish and bay anchovy in estuarine habitats of the Middle Atlantic Bight (MAB) (e.g. Buckel \& Conover 1997, Jung \& Houde 2004), yet both species are known to utilize inner continental shelf nursery habitats in addition to estuaries (Able \& Fahay 1998). Mature bluefish spawn in offshore continental shelf habitats as the population migrates northward along the US Atlantic coast during the spring and the summer, a process that typically results in 2 temporally segregated juvenile cohorts that preferentially recruit to estuary and inner shelf habitats of the MAB during the spring and summer, respectively (Kendall \& Walford 1979, Callihan et al. 2008). Bay anchovy spawn within estuaries and inner shelf waters (Able \& Fahay 1998), with juveniles apparently recruiting to proximal suitable nursery areas, although the natal source of juveniles captured in either region has not been fully verified. Due to physicochemical, physical, and biological differences between estuary and inner continental shelf (hereinafter called 'shelf') habitats, juvenile cohorts of either species that recruit to one or the other habitat are likely to experience dissimilar nursery conditions.

We used morphometric, isotopic, and dietary data to test 3 hypotheses relating nursery habitat suitability at the seascape scale (i.e. 1 to $100 \mathrm{~km}$ ) to trophic ecology for 2 species representing contrasting trophic positions. Specifically, we hypothesized that (1) vertical trophic position does not differ significantly between shelf and estuarine cohorts despite the likelihood of regional differences in specific diet compo-

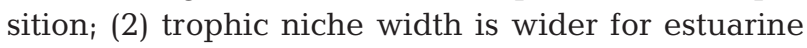
cohorts due to the increased heterogeneity of physical and geochemical attributes of estuarine habitats; and (3) cohorts from each habitat will exhibit similar physiological condition.

\section{MATERIALS AND METHODS}

\section{Fish collection}

Specimens of both species were collected by trawl during August 2008 (Table 1). Shelf samples were collected from Maryland's inner continental shelf (5 to $20 \mathrm{~m}$ depth; Fig. 1) as part of a larger, multi-year fisheries independent trawl survey (see Callihan et al. 2008 and Woodland et al. 2011 for additional survey details). Shelf bluefish $(\mathrm{n}=27)$ and bay-anchovy $(\mathrm{n}=31)$ specimens were randomly selected from total catches of a $30 \mathrm{~m}$ foot-rope demersal Yankee otter trawl or a fixed frame $1 \mathrm{~m}^{2}$ Tucker trawl (bay anchovy only). Contemporaneous estuarine specimens were collected from the polyhaline lower mainstem Chesapeake Bay, VA (hereinafter called 'estuary'; salinity: 
Table 1. Pomatomus saltatrix and Anchoa mitchilli. Sampling effort by location in Maryland's inner continental shelf (shelf, August 9-10) and Chesapeake Bay (estuary, August 4-21) in 2008. Average ( \pm SD) depth, temperature, salinity, and number/type of samples collected: length-weight analysis (size), stomach contents (diet), stable isotope (SI) for age-0 P. saltatrix and A. mitchilli. Sample size for taxa analyzed to describe the isotopic baseline of pelagic (shelf: bulk zooplankton [100-250 $\mu \mathrm{m}$ ], estuary: Crassostrea virginica) and benthic (shelf: Neverita duplicata) food webs is given. (-) Locations not sampled with a trawl, or locations in which sample size for a particular taxon was 0

\begin{tabular}{|c|c|c|c|c|c|c|c|c|c|}
\hline \multirow[t]{2}{*}{ Habitat } & \multirow[t]{2}{*}{ Location } & \multirow{2}{*}{$\begin{array}{c}\text { Effort } \\
\text { (no. of trawls) }\end{array}$} & \multirow{2}{*}{$\begin{array}{c}\text { Depth } \\
(\mathrm{m})\end{array}$} & \multirow{2}{*}{$\begin{array}{l}\text { Temp. } \\
\left({ }^{\circ} \mathrm{C}\right)\end{array}$} & \multirow[t]{2}{*}{ Salinity } & \multicolumn{2}{|c|}{ Teleosts (n for size, diet, SI) } & \multicolumn{2}{|c|}{ Baseline taxa ( $\mathrm{n}$ for $\mathrm{SI}$ ) } \\
\hline & & & & & & P. saltatrix & A. mitchilli & Pelagic & Benthic \\
\hline Shelf & Inner shelf & 8 & $12.8 \pm 3.3$ & $20.5 \pm 2.0$ & $31.7 \pm 0.8$ & $36,27,14$ & $31,30,15$ & 5 & 6 \\
\hline Estuary & Mainstem & 4 & $9.1 \pm 3.8$ & $24.8 \pm 1.5$ & $23.7 \pm 4.1$ & $30,26,16$ & $45,38,16$ & - & - \\
\hline & Location $1^{\mathrm{a}}$ & - & 1.5 & $27.2 \pm 0.4$ & $18.9 \pm 0.9$ & - & - & 10 & - \\
\hline & Location $2^{\mathrm{a}}$ & - & 1.5 & $27.9 \pm 0.6$ & $19.9 \pm 0.8$ & - & - & 5 & - \\
\hline & Location $3^{\mathrm{a}}$ & - & 2.0 & $24.1 \pm 1.6$ & $13.5 \pm 0.9$ & $26^{\mathrm{b}},-,-$ & - & 5 & - \\
\hline
\end{tabular}

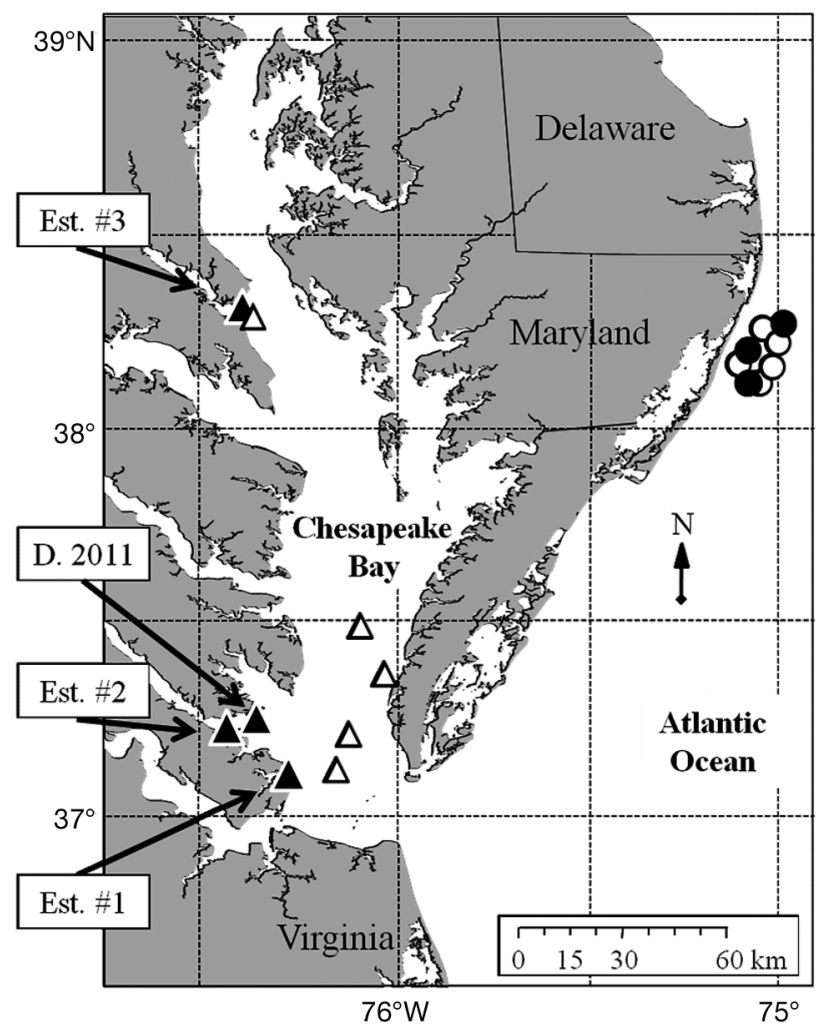

Fig. 1. Locations of teleost $(\mathrm{O}, \Delta)$ and invertebrate trophic baseline $(\boldsymbol{O}, \boldsymbol{\Delta})$ collection/cage sites in Maryland's inner continental shelf $(\boldsymbol{O}, \mathbf{O})$ and mainstem Chesapeake Bay $(\boldsymbol{\Lambda}$, $\Delta$ ). Estuarine Locations 1, 2, and 3 (Est. \#1, \#2, and \#3, respectively) and the collection site of Douglass et al. (2011) (D. 2011; source of estuarine benthic baseline estimates) are indicated

14.5 to 30.5) during the Virginia Institute of Marine Science Juvenile Fish Trawl Survey's August sampling period (Fig. 1). The estuary survey uses a demersal semi-balloon otter trawl with cod-end mesh dimensions identical to the shelf sampling $(6.4 \mathrm{~mm}$ codend mesh; see Tuckey \& Fabrizio 2009 for additional survey details). A seine was also used to capture bluefish $(\mathrm{n}=26)$ from a meso-polyhaline habitat directly adjacent to mainstem Chesapeake Bay (estuary Location 3 ; Fig. 1). In total, bluefish were available from 5 unique shelf and estuary trawl locations and 1 estuary seine location. Bay anchovy were available from 4 and 1 unique shelf and estuary locations, respectively. Specimens were collected from depths of $12.8 \pm 3.2 \mathrm{~m}$ (mean $\pm \mathrm{SD}$ ) in the shelf and $9.1 \pm 3.8 \mathrm{~m}$ in the estuary. Specimens retained for stable isotope and stomach contents (hereinafter called 'isotope' and 'diet', respectively) analysis were either immediately flash-frozen on dry ice or immersed in an ice bath and transferred to a $-20^{\circ} \mathrm{C}$ freezer on the same day. All specimens were stored at $-20^{\circ} \mathrm{C}$ until analyzed. Based on published information regarding juvenile habitat use by bay anchovy (Able \& Fahay 1998) and the isotopic composition of age-0 bluefish otoliths from an earlier pilot study (see sections S1.2 to S2.2 in the supplement at www.int-res.com/articles/ suppl/m439p241_supp.pdf), we assumed specimens recruited as early juveniles and remained resident in the habitat (i.e. shelf vs. estuary) from which they were captured.

Bluefish collected in the shelf (total length: $148 \pm$ $19 \mathrm{~mm}_{\text {; }}$ mean $\left.\pm \mathrm{SD}\right)$ were smaller (2-sample $t$-test: $t=$ $7.40, \mathrm{df}=42.04, \mathrm{p}<0.0001)$ than those collected by trawl in the estuary (total length: $203 \pm 37 \mathrm{~mm}$ ). There was no difference $(t=0.60, \mathrm{df}=74, \mathrm{p}=0.55)$ in size distribution of bay-anchovy specimens between habitats (shelf: $44 \pm 7 \mathrm{~mm}$, estuary: $45 \pm 7 \mathrm{~mm}$ ). Due to the size difference of shelf versus estuary bluefish, 
we used an ancillary multi-year data set of bluefish diet data to test the hypothesis that diet varies significantly between length classes of age-0 bluefish pertinent to the present study (see section S1.1 in the supplement). Results from this analysis showed no difference in multivariate diet between length classes of bluefish 125-174 and 225-274 $\mathrm{mm}$ in mainstem Chesapeake Bay habitats (2-way analysis of similarity [ANOSIM]: $R$-statistic $=0.20, \mathrm{p}=0.18$; Clarke 1993).

\section{Establishing trophic baselines}

Aquatic habitats often display distinct geochemical properties that propagate through local food webs. Such differences in isotopic signatures can invalidate cross-habitat comparisons of trophic structure unless isotope data have been standardized to a common reference level or 'trophic baseline' (Post 2002). Consumers of known trophic level can integrate the temporally variable isotopic signature of autotrophic food web components, permitting analysis of trophic structure between disparate food webs (Cabana \& Rasmussen 1996). In the case of shelf and estuarine ecosystems, there are generally 2 proximate $\mathrm{C}$ and $\mathrm{N}$ sources for secondary consumers: a pelagic food web, derived primarily from phytoplankton production; and a benthic food web based on production by epiphytic or substrate-associated algae. To account for these 2 potential nutrient sources to bluefish and bay anchovy, we used planted and naturally occurring consumers of known trophic position to estimate trophic baselines for $\delta^{13} \mathrm{C}$ and $\delta^{15} \mathrm{~N}$ in each habitat.

The eastern oyster Crassostrea virginica (hereinafter called 'oysters') was selected as a pelagic baseline species (trophic level [TL] = 2) for both habitats. This euryhaline species (naturally occurring in salinities 2 to 40 ; Shumway 1996) is native to many coastal ecosystems of the eastern USA and it has been shown to recapitulate the isotopic signature of local seston in Chesapeake Bay (Fertig et al. 2010). Because $\delta^{13} \mathrm{C}$ and $\delta^{15} \mathrm{~N}$ of bivalves undergo relatively predictable enrichment patterns along the salinity gradient (Fry 2002, Fertig et al. 2010), the isotope signature of oysters from a single location in Chesapeake Bay is unlikely to reflect the admixture of isotopic inputs integrated by mainstem food webs. To allow multiple locations to be sampled while guaranteeing the availability of specimens, cages of oysters were deployed in lower Chesapeake Bay and the continental shelf (shelf-planted oysters did not survive, see below, this section, for further discussion).

Age-1 oysters reared under mesohaline conditions were obtained in April 2008 from the Maryland Sea Grant Oyster Gardening Program and transferred to an unfiltered, ambient flow-through raceway at Chesapeake Biological Laboratory (estuary Location 3: $38^{\circ} 19.1^{\prime} \mathrm{N}, 76^{\circ} 27.1^{\prime} \mathrm{W}$, intake $\sim 2 \mathrm{~m}$ below surface). In July, a subsample of these oysters was transferred to cages at 2 locations proximal to fish collection sites in the estuary and on the shelf. At the estuarine locations (Location 1: $37^{\circ} 5.6^{\prime} \mathrm{N}, 76^{\circ} 20.7^{\prime} \mathrm{W}$ and Location 2: $\left.37^{\circ} 14.9^{\prime} \mathrm{N}, 76^{\circ} 30.4^{\prime} \mathrm{W}\right), 4$ oysters were held in each of 3 polyethylene $2.54 \mathrm{~cm}^{2}$ bar mesh cages ( $\mathrm{n}=12$ per location) that were suspended $0.5 \mathrm{~m}$ above the bottom on a vertical tether stretched between a cement anchor and surface float at depths of 1.5 to $2 \mathrm{~m}$. Oysters were allowed to equilibrate in situ at estuarine Locations 1 and 2 for $70 \mathrm{~d}$, at which time all surviving specimens from the cages $(\mathrm{n}=11$ at Locations 1 and 2) and the Chesapeake Biological Laboratory raceway ( $\mathrm{n}=5$ at Location 3 ) were collected, frozen, and stored at $-20^{\circ} \mathrm{C}$. To verify equilibration of the planted oysters to local biogeochemical conditions, we collected wild oysters at estuary Location 1 for isotope analysis. Initial testing indicated planted oysters had not yet equilibrated to local isotopic conditions at estuary Location 1 after the $70 \mathrm{~d}$ period (2-sample $t$-test: $t=3.51, \mathrm{df}=8, \mathrm{p}=0.008$ ). To account for this, we modeled the monthly equilibration rate of caged oysters at Location 1 with a growthbased mixing model (Hesslein et al. 1993) and used the resulting equilibration rate $(0.46 \pm 0.04$ [asymptotic SD] $\mathrm{mo}^{-1}$ ) to predict the eventual equilibrium isotope value of caged oysters at estuary Location 2 (see section S1.2 in the supplement). Oysters at estuary Location 3 had been held at constant conditions from April to August and were assumed to have reached equilibrium with the local pelagic phytoplankton signature (Fertig et al. 2010). An appropriate benthic baseline species was not available from estuarine sampling; therefore, we used the grand mean of the reported average isotope values of a littoral grazer community (2 amphipods Ampithoe longimana, Gammarus mucronatus; 1 isopod Erichsonella attenuate; and 1 caridean shrimp Hippolyte pleuracanthus; Douglass et al. 2011) collected in August 2005 from a seagrass bed at the mouth of the York River, VA (Fig. 1).

Oysters $(n=24)$ transplanted to the shelf suffered intense predation that precluded their use as a pelagic shelf baseline. Instead, bulk zooplankton of size 100 to $250 \mu \mathrm{m}$ were used as a trophic level = 
2 proxy trophic baseline. A 201 seawater sample was collected from near-bottom (0.5 to $1 \mathrm{~m}$ above bottom), mid-water, and surface ( 0.5 to $1 \mathrm{~m}$ below surface) at each trawl site during teleost sampling. Water samples were mixed prior to filtration (total 60 l); therefore, zooplankton isotope values represent a surfaceto-bottom integration of the planktonic community. The Atlantic moon snail Neverita duplicata, a carnivorous gastropod (trophic level = 3) and common component of the trawl bycatch on the shelf, was selected as the benthic shelf baseline species. Moon snails were immediately transferred to dry ice, whereas zooplankton samples were held in $0.7 \mu \mathrm{m}$-filtered ambient seawater for $6 \mathrm{~h}$ before freezing on dry ice.

\section{Stable isotope analysis}

Teleosts were partially thawed and a sample of dorsal epaxial muscle tissue removed and cleaned of residual intermuscular bones. Samples were rinsed in deionized water, held at $60^{\circ} \mathrm{C}$ for $\geq 48 \mathrm{~h}$ until completely dried, then pulverized to a fine homogenous powder using a mortar and pestle. For invertebrate taxa, the adductor muscle of oysters $(n=5$ per estuary location) and a portion of the muscular 'foot' of moon snails $(n=6)$ were removed and rinsed. Zooplankton $(n=5) \mathrm{C}$ samples were acid-fumigated with $1 \mathrm{~N} \mathrm{HCl}$ and lightly rinsed in deionized water before drying to remove inorganic carbonates (separate $\mathrm{N}$ samples were not acid-fumigated). After drying, all invertebrate samples were handled identically to the teleost tissue samples. Powdered samples were analyzed for $\mathrm{C}$ and $\mathrm{N}$ isotope composition on a continuous-flow isotope ratio mass spectrometer coupled with an elemental analyzer (EA-CFIRMS; Colorado Plateau Stable Isotope Laboratory, Northern Arizona University). Isotope values are reported as a ratio in the ' $\delta$ ' notation (Peterson \& Fry 1987) relative to international standards: Pee Dee Belemnite (C) and ambient air (N). With the exception of 2 zooplankton samples (C:N ratio: 4.7 and 4.8 ), all sample $\mathrm{C}: \mathrm{N}$ ratios were $<4.0$; therefore $\delta^{13} \mathrm{C}$ values were not mathematically normalized for lipid content (Kiljunen et al. 2006, Post et al. 2007).

\section{Condition factors}

Species condition was compared between habitats with a residual length-weight index and a stoichiometric proxy for lipid content. The residual index of individual condition was calculated by regressing $\log _{10}$ (body mass) against $\log _{10}$ (total length) for each species from both habitats combined and calculating the residual for each observation (e.g. Quevedo et al. 2009). Residuals were then analyzed with $t$-tests to compare species weight-at-length between habitats. Due to the significant difference in length between bluefish from the shelf and estuary in August, estuary bluefish captured by seine in July (total length: $150 \pm 42 \mathrm{~mm}$; mean $\pm \mathrm{SD}$ ) were included in the residual condition index calculations to maintain sufficient size overlap between the 2 habitats for a robust comparison. We used the $\mathrm{C}: \mathrm{N}$ ratio of muscle tissue, calculated during mass spectroscopy, as a physiochemical index of individual condition representing energy storage (i.e. proxy for sample \% lipid content; Mcconnaughey \& Mcroy 1979, Post et al. 2007, Buchheister \& Latour 2010). Specifically, an estimate of the \% lipid content of each sample was calculated using the linear transformation presented by Post et al. (2007). The relationship between C:N ratio and \% lipid content is a function of the hydrocarbon chain structure of lipids, which conveys a relatively higher $\mathrm{C}$ content per unit mass than the nitrogenous amino acid composition of lean muscle tissue. The C:N lipid proxy was compared between habitats for both species using ANOVA (for bluefish, we compared shelf values to both July and August estuary values).

\section{Trophic niche characteristics}

Species distributions in bivariate isotope space were used to analyze spatial differences in trophic ecology, including indicators of trophic variability, niche width, and total niche area. Species-specific $\delta^{15} \mathrm{~N}$ and $\delta^{13} \mathrm{C}$ variances were contrasted (Levene's test) to determine if isotopic niche width differed between habitats (Bearhop et al. 2004). The extent of trophic dependency on pelagic versus benthic sources was quantified as the proportion of $\mathrm{C}$ derived from pelagic versus benthic/littoral food webs ( $\mathrm{P}_{\text {Pelagici }}$ e.g. Quevedo et al. 2009). Total niche area (TA) was calculated as the minimum convex hull area in $\delta^{15} \mathrm{~N}$ and $\delta^{13} \mathrm{C}$ space (Cornwell et al. 2006, Layman et al. 2007). Convex hull area provides an index of realized niche space; although it was initially described as a community-wide metric of niche width (Layman et al. 2007), it has since been applied at the population level by using individuals as sampling units (e.g. Atkinson et al. 2010, Zambrano et al. 2010, Kovalenko \& Dibble 2011). Bootstrapping (unrestricted random sampling with replacement; $\mathrm{n}=50$ ) was used to generate replicate 
distributions of TA to allow statistical comparisons of mean TA between habitats for each species (statistical power $\beta=0.70$ to 0.99 at theoretical TA differences of 0.5 to $1.0 \%{ }^{2}$ ).

Trophic position of bluefish and bay anchovy from each habitat was estimated directly from diet and $\delta^{15} \mathrm{~N}$ signatures. Stomachs were excised from thawed specimens and fixed in $10 \%$ buffered formalin solution prior to diet analysis. Prey items were identified to the lowest possible taxon, enumerated, blotted dry, and weighed (nearest mg). Percent diet composition by weight (Hyslop 1980) was aggregated into 17 (bluefish) or 8 (bay anchovy) unique prey categories. Trophic position of bluefish and bay anchovy was calculated for each habitat from diet data. For each specimen, the proportion of the total stomach contents biomass contributed by each prey taxon was weighted by trophic position estimates of prey that were taken directly from the literature or estimated based on published diets of prey taxa (e.g. Winemiller et al. 2007). The deviation of $\delta^{15} \mathrm{~N}$ values from the pelagic and benthic baselines, weighted by the species- and habitat-specific estimated contribution of each food web (pelagic: $\mathrm{P}_{\text {Pelagic }}$ benthic: $1-\mathrm{P}_{\text {pelagic }}$ ) and divided by an estimate of $\mathrm{N}$ fractionation between trophic levels $\left(\Delta_{N}\right)$, were used to calculate isotope-based estimates of trophic position. In the absence of specific estimates of $\Delta_{\mathrm{N}}$ between bluefish, bay anchovy, and their prey, we selected a general value of 3.4\% (Post 2002) and assumed this value was broadly representative of $\Delta_{\mathrm{N}}$ across trophic transfers for the communities supporting these species in estuarine and shelf habitats. Two-sample $t$-tests were used to test for spatial patterns in trophic position and agreement between isotope and dietbased estimates of trophic position.

\section{RESULTS}

\section{Isotopic baseline estimates}

Oysters had mean $( \pm \mathrm{SD})$ isotope values of $\delta^{13} \mathrm{C}=$ $-21.08 \pm 0.78 \%$ and $\delta^{15} \mathrm{~N}=10.37 \pm 0.71 \%$ at estuary Location 1 , and $\delta^{13} \mathrm{C}=-21.03 \pm 0.16 \%$ and $\delta^{15} \mathrm{~N}=$ $14.12 \pm 0.11 \%$ at estuary Location 3 (Fig. 2). Estimated equilibrium values of oysters at Location 2 were similar for $\delta^{13} \mathrm{C}(-20.41 \pm 0.23 \%)$ and intermediate between Locations 1 and 3 in terms of $\delta^{15} \mathrm{~N}$ $(12.68 \pm 0.12 \%)$. The final isotopic signature of the pelagic estuarine baseline was $-20.81 \pm 0.54 \%$ for $\delta^{13} \mathrm{C}$ and $12.41 \pm 1.59 \%$ for $\delta^{15} \mathrm{~N}$. The estuary benthic baseline, calculated from values reported by Dou-

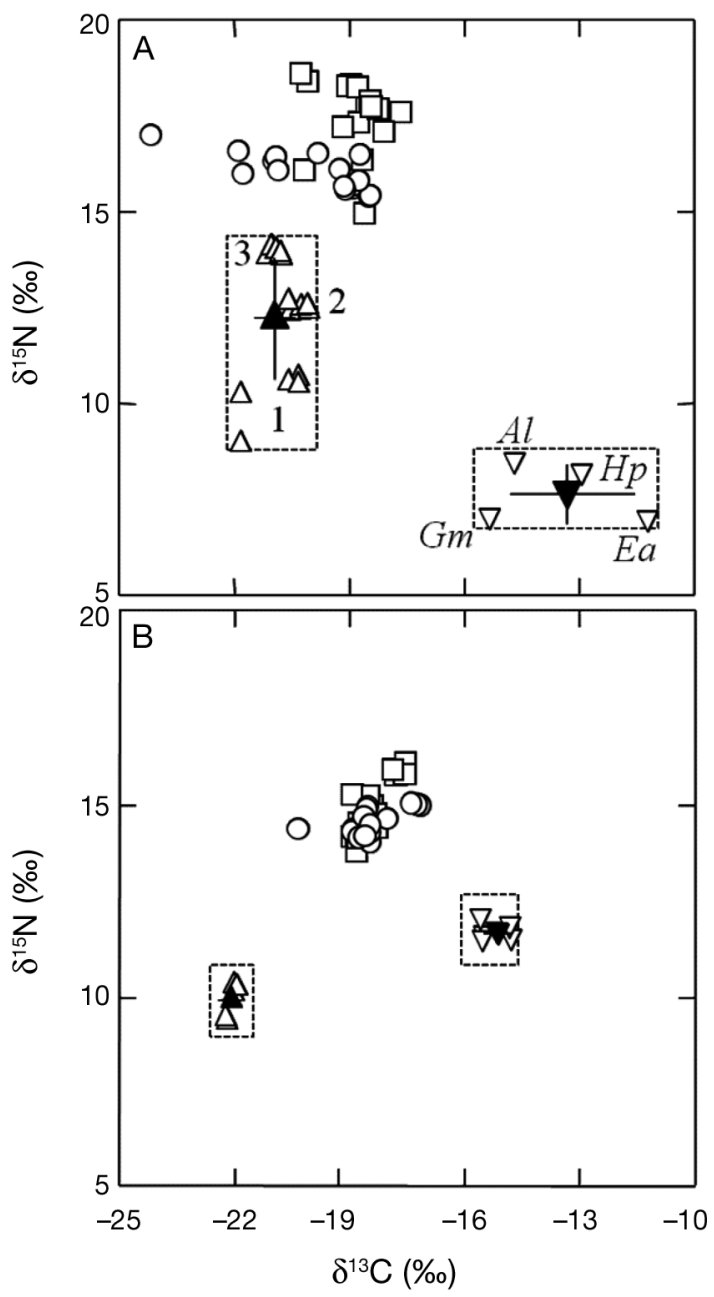

Fig. 2. Pomatomus saltatrix and Anchoa mitchilli. $\delta^{13} \mathrm{C}$ and $\delta^{15} \mathrm{~N}$ data for age-0 P. saltatrix $(\square), A$. mitchilli $(\mathrm{O})$, and pelagic $(\Delta)$ and benthic $(\nabla)$ trophic baseline taxa from (A) mainstem Chesapeake Bay (estuary) and (B) Maryland's inner continental shelf (shelf). Estuary baseline taxa: pelagic $=$ Crassostrea virginica (labeled according to estuary collection Locations 1, 2, and 3, see Fig. 1), benthic = mixed grazer community (Gm: Gammarus mucronatus, Al: Ampithoe longimana, Hp: Hippolyte pleuracantha, Ea: Erichsonella attenuata; from Douglass et al. 2011). Shelf baseline taxa: pelagic $=$ bulk zooplankton $(100-250 \mu \mathrm{m})$, benthic $=$ Neverita duplicata. Filled symbols ( $\boldsymbol{\Lambda}$, pelagic; $\boldsymbol{\nabla}$, bentic): mean $( \pm \mathrm{SD})$ trophic baseline signatures; dashed rectangles enclose baselines

glass et al. (2011), was $-13.66 \pm 1.86 \%$ or for $\delta^{13} \mathrm{C}$ and $7.74 \pm 0.78 \%$ for $\delta^{15} \mathrm{~N}$ (Fig. 2). On the shelf, zooplankton (pelagic baseline) $\delta^{13} \mathrm{C}$ was $-22.13 \pm 0.15 \%$ and $\delta^{15} \mathrm{~N}$ was $10.00 \pm 0.48 \%$; whereas the $\delta^{13} \mathrm{C}$ of moon snails (benthic baseline corrected to trophic level $=2$ ) was $-15.35 \pm 0.38 \%$ ond the $\delta^{15} \mathrm{~N}$ was $8.39 \pm 0.21 \%$ o after accounting for the community-wide estimate of $\Delta_{\mathrm{N}}$ between trophic levels. 


\section{Condition factors}

The regression of $\log _{10}$ (body mass) against $\log _{10}$ (total length) was significant for bluefish (slope $=$ $\left.3.28 \pm 0.04 \mathrm{SE}, \mathrm{r}^{2}=0.99, F_{1,90}=6.150, \mathrm{p}<0.001\right)$ and bay anchovy (slope $=3.28 \pm 0.12 \mathrm{SE}, \mathrm{r}^{2}=0.91, F_{1,74}=$ $761, p<0.001)$. There was no difference in condition residuals of shelf bluefish versus estuarine bluefish $(F=3.12, \mathrm{df}=88, \mathrm{p}=0.08$; Fig. 3). The C:N-based proxy of lipid content for shelf bluefish was higher than estuarine bluefish in July $(t=3.95, \mathrm{df}=42$, Tukey-adjusted $\mathrm{p}=0.0003)$ and in August $(t=5.74$, $\mathrm{df}=42$, Tukey-adjusted $\mathrm{p}<0.0001$; Fig. 3). For bay anchovy, condition residuals were significantly higher $(t=-3.63, \mathrm{df}=74, \mathrm{p}=0.001)$ in fish from the shelf (mean residual $=0.03 \pm 0.05 \mathrm{SD}$ ) than those from the estuary $(-0.02 \pm 0.07$; Fig. 3). Similarly, the
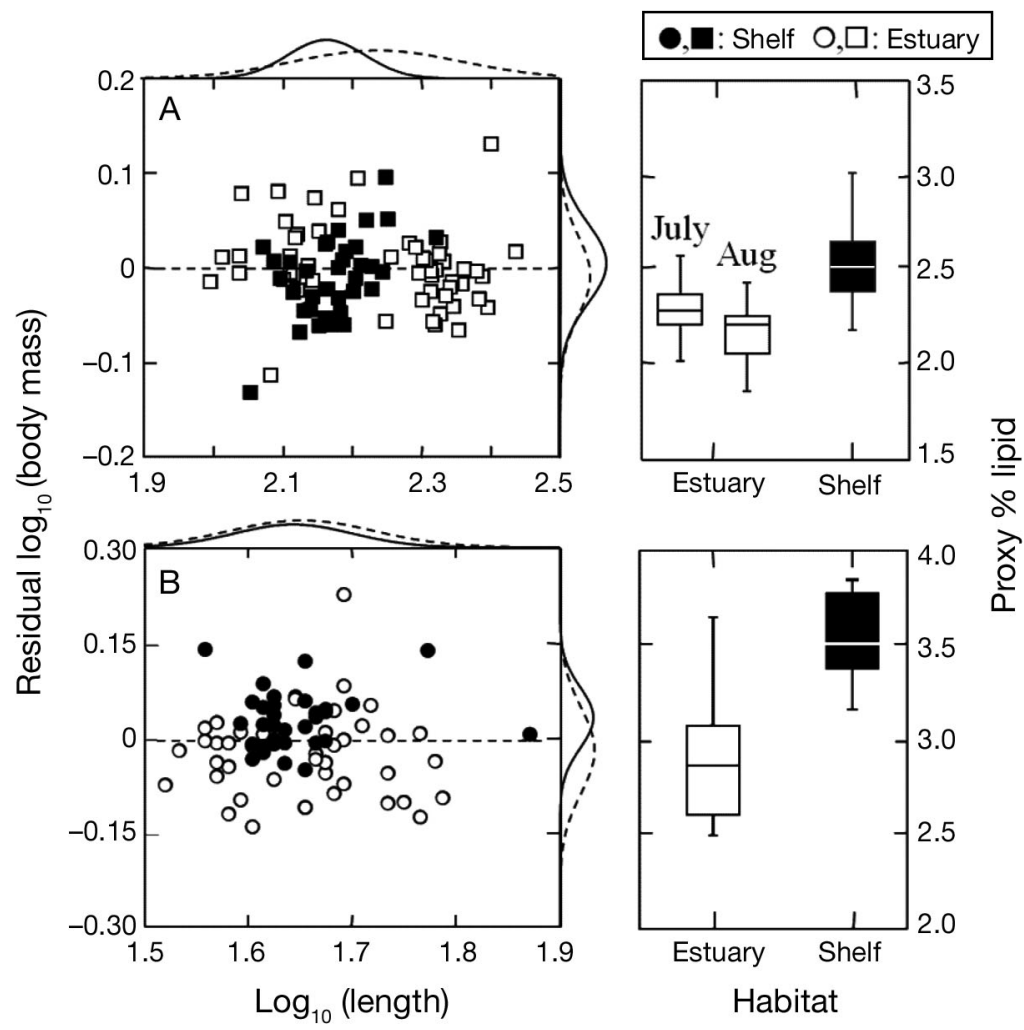

Fig. 3. Pomatomus saltatrix and Anchoa mitchilli. Residuals from linear regression of $\log _{10}$ (body mass) on $\log _{10}$ (length) for age- 0 P. saltatrix (A: upper left panel) and A. mitchilli (B: lower left panel) plotted against $\log _{10}($ length) from Maryland's inner continental shelf (Shelf) and lower mainstem Chesapeake Bay (Estuary). Normal distributions fitted to shelf (solid line) and estuary (dashed line) data are given along the secondary axes. Box plots show distributions for a proxy of \% lipid content (as estimated from C:N ratio data) from each habitat for P. saltatrix (A: upper right panel) and A. mitchilli (B: lower right panel). Individual box plots provided for July and August estuarine $P$. saltatrix. Box plots show median (horizontal line), $50 \%$ range of values (box), and $1.5 \times$ the interquartile range (whiskers)
$\mathrm{C}: \mathrm{N}$ percent lipid proxy was significantly higher $(t=$ $6.52, \mathrm{df}=29, \mathrm{p}<0.001$ ) among bay anchovy from the shelf $(3.57 \pm 0.23 \% \mathrm{SD})$ versus those from the estuary $(2.90 \pm 0.33 \%$; Fig. 3$)$.

\section{Trophic niche characteristics}

$\mathrm{C}$ isotope values for bluefish ranged from -18.98 to $-17.56 \%$ in the shelf and -20.38 to $-17.75 \%$ in the estuary (Table 2, Fig. 2). Bluefish $\delta^{15} \mathrm{~N}$ values ranged from 13.88 to $16.21 \%$ (shelf) and 15.09 to $18.73 \%$ (estuary). Bay anchovy isotope values ranged from -20.40 to $-17.17 \%$ o (shelf) and -24.27 to $-18.55 \%$ (estuary) for $\delta^{13} \mathrm{C}$, and from 14.13 to $15.14 \%$ (shelf) and 15.51 to $17.11 \%$ (estuary) for $\delta^{15} \mathrm{~N}$. Variance of $\delta^{13} \mathrm{C}$ was equivalent $\left(F_{15,13}=2.17, \mathrm{p}=0.17\right)$ between habitats for bluefish but it was less variable $\left(F_{15,14}=4.15, \mathrm{p}=0.01\right)$ for shelf bay anchovy than estuary bay anchovy (Table 2). Variance was similar for $\delta^{15} \mathrm{~N}$ $(F \leq 4.74, \mathrm{p} \geq 0.26)$ between habitats for bluefish and bay anchovy (Table 2). Trophic niches of bluefish $\left(\mathrm{P}_{\text {Pelagic }}=0.83\right.$ $\pm 0.06)$ and bay anchovy ( $P_{\text {Pelagic }}=0.93 \pm$ 0.14 ) were tightly linked to the pelagic food web in the estuary, whereas shelf cohorts showed more equitable contributions between pelagic and benthic food webs $\left(\mathrm{P}_{\text {Pelagic }}=0.45 \pm 0.07\right.$ and $0.46 \pm 0.12$ for bluefish and bay anchovy, respectively; Fig. 4). For both species, shelf $\mathrm{P}_{\text {Pelagic }}$ was lower than estuary $\mathrm{P}_{\text {Pelagic }}$ (2-sample $t \geq 10.28, \mathrm{p}<0.0001)$. Comparisons of bootstrapped TA distributions indicated that TA was significantly higher for both species in the estuary (paired $t$-tests $>$ 8.72, p $<0.0001$ ). Observed TA was 1.6-fold higher in the estuary than the shelf for bluefish and 2.5-fold higher in the estuary for bay anchovy (Table 2).

Stomach contents of bluefish in the shelf $(\mathrm{n}=27$; trophic position $=4.20 \pm$ $0.09 \mathrm{SD}$ ) were primarily composed of fish and cephalopod remains that included anchovy (Anchoa spp. made up 59\% of total stomach contents biomass), squid (Loligo spp.: $13 \%$ ), and Atlantic butterfish (Peprilus triacanthus: 13\%) (Fig. 5). Conversely, the diet of estuarine bluefish $(\mathrm{n}=26$; trophic position $=4.15 \pm 0.06)$ was dominated by anchovy (88\%) and 
Table 2. Pomatomus saltatrix and Anchoa mitchilli. Stable isotope $\left(\delta^{13} \mathrm{C}, \delta^{15} \mathrm{~N}\right)$ and diet-based trophic niche metric values $( \pm \mathrm{SD})$ for age-0 P. saltatrix and A. mitchilli from Maryland's inner continental shelf (shelf) and lower mainstem Chesapeake Bay (estuary) from August 2008. TP: trophic position (SI: stable isotope, SC: stomach contents), $P_{\text {Pelagic: }}$ proportion of biomass derived from pelagic food web, TA: convex hull area in $\delta^{13} \mathrm{C}-\delta^{15} \mathrm{~N}$ space (observed value given with bootstrapped mean $\pm \mathrm{SD}$ in parentheses)

\begin{tabular}{|lcccrrr}
\hline $\begin{array}{l}\text { Species } \\
\text { Habitat }\end{array}$ & $\delta^{13} \mathrm{C}(\%)$ & $\delta^{15} \mathrm{~N}(\%)$ & $\mathrm{TP}_{\mathrm{SI}}$ & $\mathrm{TP}_{\mathrm{SC}}$ & $\mathrm{P}_{\text {Pelagic }}$ & $\mathrm{TA}\left(\%{ }^{2}\right)$ \\
\hline $\begin{array}{l}\text { P. Saltatrix } \\
\quad \text { Shelf }\end{array}$ & $-18.40 \pm 0.51$ & $15.03 \pm 0.77$ & $3.97 \pm 0.29$ & $4.2 \pm 0.09$ & $0.45 \pm 0.07$ & $1.52(1.11 \pm 0.25)$ \\
$\quad$ Estuary & $-18.97 \pm 0.75$ & $17.60 \pm 0.97$ & $4.09 \pm 0.32$ & $4.15 \pm 0.06$ & $0.83 \pm 0.06$ & $2.44(1.94 \pm 0.45)$ \\
A. mitchilli & & & & & & \\
$\quad$ Shelf & $-18.46 \pm 0.79$ & $14.66 \pm 0.35$ & $3.84 \pm 0.16$ & $3.51 \pm 0.17$ & $0.46 \pm 0.12$ & $1.56(1.14 \pm 0.31)$ \\
$\quad$ Estuary & $-20.11 \pm 1.61$ & $16.17 \pm 0.48$ & $3.52 \pm 0.10$ & $3.5 \pm 0.06$ & $0.93 \pm 0.14$ & $3.85(2.45 \pm 0.86)$ \\
\hline
\end{tabular}

clupeids (unidentified Clupeidae: $9 \%$ ), with mantis shrimp (Squilla empusa: 2\%) representing the only invertebrate consumed. Despite a statistical difference in trophic position of bluefish between habitats $(t=2.26, \mathrm{df}=44.98, \mathrm{p}=0.03)$, the magnitude of the difference $(=0.05)$ suggests it is unlikely to be ecologically significant. There was no difference

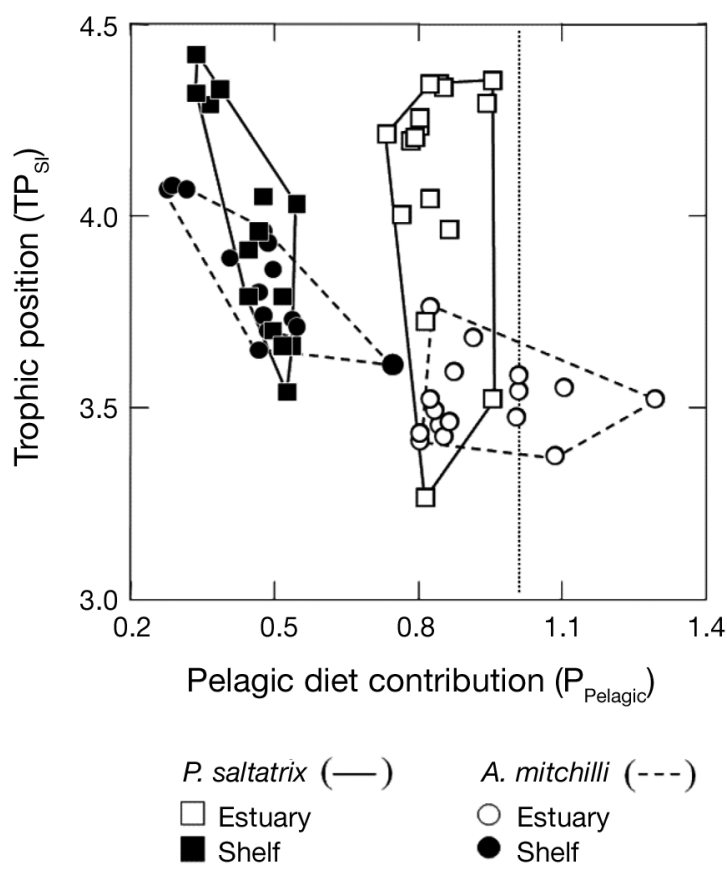

Fig. 4. Pomatomus saltatrix and Anchoa mitchilli. Trophic position based on stable isotopes $\left(\mathrm{TP}_{\mathrm{SI}}\right)$ plotted against proportion of diet derived from pelagic food webs ( $\mathrm{P}_{\text {Pelagic }}$ ) for age- 0 P. saltatrix and $A$. mitchilli from Maryland's inner continental shelf (shelf) and lower mainstem Chesapeake Bay (estuary). Both metrics estimated from $\delta^{13} \mathrm{C}$ and $\delta^{15} \mathrm{~N}$ data. Polygons contain data for each species-habitat combination. Maximum theoretical contribution of local pelagic food webs to consumers (i.e. $P_{\text {Pelagic }}=1.0$ based on trophic base lines) is shown (fine dotted vertical line) between isotope-based estimates of bluefish trophic position between habitats ( $p=0.31$; Table 2, Fig. 4). Isotope estimates of trophic position were lower than

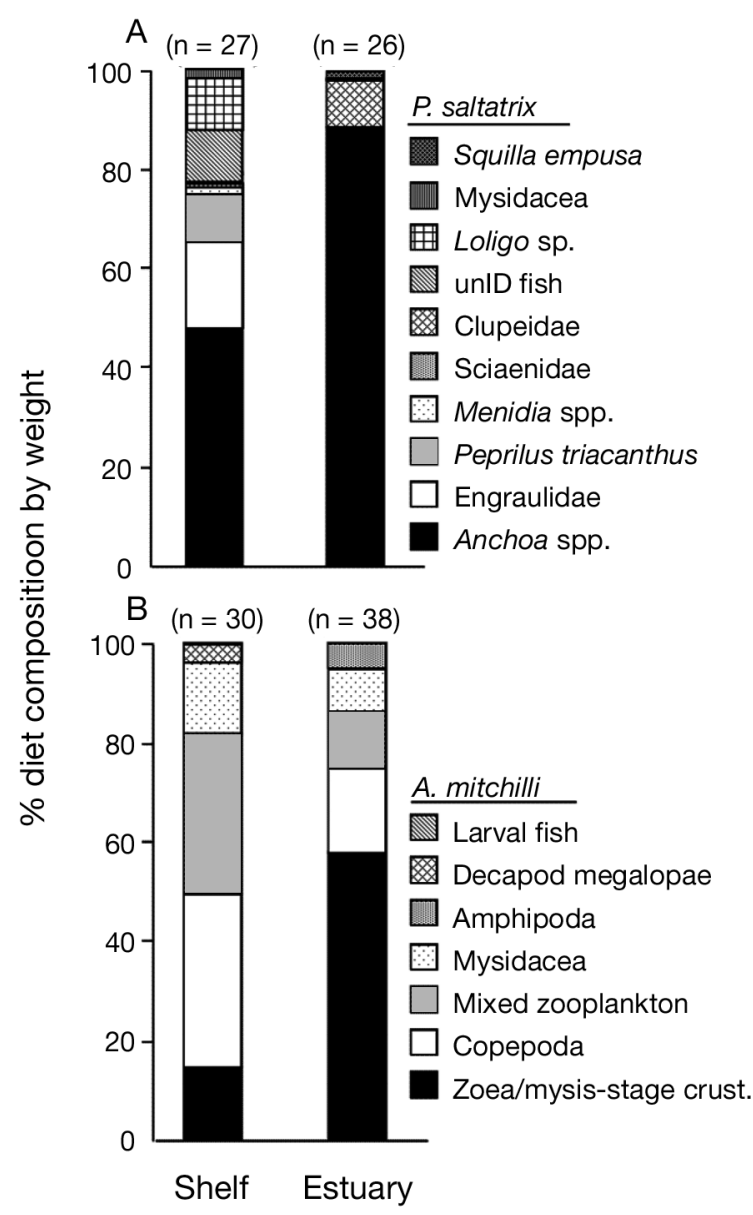

Fig. 5. Pomatomus saltatrix and Anchoa mitchilli. Stomach contents data for age-0 (A) P. saltatrix and (B) A. mitchilli from Maryland's inner continental shelf (shelf) and lower mainstem Chesapeake Bay (estuary). crust.: crustaceans, unID: unidentified 
diet-based estimates in the shelf $(t=3.71, \mathrm{df}=39, \mathrm{p}=$ $0.0006)$ but were similar in the estuary $(p=0.36)$.

Bay-anchovy diets were more evenly distributed than bluefish diets, with 4 prey categories-Copepoda, mixed zooplankton (e.g. fish eggs, bivalve larvae, ostracods), Mysidacea, and larval (i.e. zoea/ mysis stage) crustaceans - contributing $86 \%$ of total stomach contents biomass of the shelf sample $(\mathrm{n}=31$; prey categories $=31,29,13$, and $13 \%$ respectively) and $94 \%$ of the estuary sample $(\mathrm{n}=45$; prey categories $=17,11,9$, and $57 \%$ ) specimens (Fig. 5). Dietbased estimates of bay-anchovy trophic position, $3.51 \pm 0.17$ in the shelf and $3.44 \pm 0.40$ in the estuary, were not significantly different $(t=0.20, \mathrm{df}=66, \mathrm{p}=$ 0.83). Isotope-based estimates of bay-anchovy trophic position showed the same pattern but were significantly higher $(t=6.56, \mathrm{df}=29, \mathrm{p}<0.001)$ in the shelf $(3.84 \pm 0.16)$ than the estuary $(3.53 \pm 0.10$; Table 2, Fig. 4). A comparison of estimation methods showed that the isotope estimate was higher than the diet estimate in the shelf $(t=-6.35, \mathrm{df}=43, \mathrm{p}<0.001)$ and equivalent to the diet-based estimate in the estuary $(\mathrm{p}=0.25)$.

\section{DISCUSSION}

Despite underlying environmental similarities that allow many marine finfish species to facultatively recruit to inner continental shelf or estuarine nurseries, significant differences in trophic ecology can arise between cohorts depending on the recruitment habitat. In the present study, the simultaneous use of stable isotope and stomach content analysis supported our initial hypothesis that the trophic niche occupied by juvenile bluefish and bay anchovy differs between inner continental shelf and estuarine nurseries. The different integration periods of these data types suggest that the observed differences in trophic niche between habitats spanned multiple temporal scales relevant to juvenile residency periods (i.e. days to weeks). Additionally, the nature and extent of habitat-specific physiological differences varied between the 2 species, indicating that the consequences of using shelf versus estuarine nursery habitats are likely to vary among taxa despite similar functional ecologies (e.g. pelagic species). By examining patterns in trophic niche and physiological condition of juvenile fish between different nursery habitats, the present study highlights the potential usefulness of trophic indicators of habitat suitability while emphasizing the need to consider speciesspecific responses to nursery conditions.

\section{Inner continental shelf vs. estuarine foraging conditions}

There was mixed support for the hypothesis that cohorts in estuaries encounter more variable foraging conditions and realize higher overall niche breadth than those recruiting to shelf habitats. For example, TA in $\delta^{13} \mathrm{C}-\delta^{15} \mathrm{~N}$ space suggested a larger trophic niche among estuarine cohorts; yet, evidence from diet and isotope mixing-models indicated that shelf cohorts were actually realizing a broader trophic niche. This discrepancy arises from the greater spread of estuarine individuals (within species) in $\delta^{13} \mathrm{C}-\delta^{15} \mathrm{~N}$ space, combined with a systematic 'skew' towards more depleted pelagic $\mathrm{C}$ signatures. Taken together, these patterns yield a higher TA estimate, but suggest a narrower realized trophic niche due to reduced utilization of benthic food webs by juvenile bay anchovy and bluefish in lower Chesapeake Bay.

The increased reliance on pelagic food webs by estuarine cohorts of both species could be linked to ecosystem-level differences in the strength of benthic-pelagic coupling between Chesapeake Bay and Maryland's inner continental shelf. Chesapeake Bay is a salt-wedge estuary that experiences seasonal stratification and chronic hypoxia during the summer that can limit benthic production (Long \& Seitz 2009) and render deeper areas unusable as foraging habitat for pelagic fish (Ludsin et al. 2009). Conversely, the water column of the inner continental shelf is typically well-mixed (Epifanio \& Garvine 2001), a property that should foster a higher connectivity between pelagic and benthic food webs. The diet analysis also supports the inference that trophic niche is wider in shelf habitats due to higher benthic-pelagic coupling. Diets of both species were more taxonomically diverse in the shelf environment and included a greater percentage of benthic and demersal organisms (e.g. mysid shrimp, juvenile Loligo sp. squid, juvenile Peprilus triacanthus). Our results suggest that juvenile bay anchovy and bluefish occupied a narrower trophic niche in lower Chesapeake Bay despite evidence of greater among-individual variability in isotopic niche space. Secondly, the data suggest that the differences in trophic niche were related to the greater utilization (or availability/ accessibility) of benthic food-web components in shelf habitats during late summer.

The source of the isotopic variability among individuals in the estuarine cohorts could reflect aspects of spatial foraging ecology and the underlying biogeochemical heterogeneity of an environment such as 
Chesapeake Bay. Evidence from tagging studies indicates that age- 0 bluefish can remain resident in localized estuary habitats (i.e. 0 to $5 \mathrm{~km}$ ) for periods of weeks to months (Morton et al. 1993, Able et al. 2003), whereas juveniles in coastal ocean habitats display higher mobility (i.e. $10+\mathrm{km}$ ) and reduced site fidelity (Morton et al. 1993, Able et al. 2003). Increased spatial mixing and, presumably, spatial foraging of shelf individuals would lead to a more homogenous isotopic signature among shelf bluefish. Individual movement data for bay anchovy are limited, but environmental reconstructions inferred from otolith microchemistry (Kimura et al. 2000) indicate age-0 bay anchovy of standard length 35 to $45 \mathrm{~mm}$ captured in polyhaline Chesapeake Bay habitats were spawned in that same salinity regime. Differences in the extent of withinhabitat spatial movements, coupled with the greater underlying biogeochemical heterogeneity of estuaries (e.g. $\delta^{13} C_{\text {; }}$ see Raymond \& Bauer's 2001 Tables 1 vs. 2), could explain the larger isotopic niche occupied by estuarine as compared to shelf cohorts. Finally, it is possible that bluefish and bay anchovy in the shelf experience different isotopic assimilation and equilibration dynamics than estuarine fish due to endogenous feedbacks between environmental conditions, prey type, metabolism, growth, and physiological condition (e.g. McCutchan et al. 2003). Such effects remain to be investigated.

\section{Trophic position}

Based on isotope data, juvenile bay anchovy occupied a slightly higher vertical trophic niche in shelf habitats relative to estuarine conspecifics, whereas there was no evidence of spatial differences in trophic position of juvenile bluefish. Due to inefficiencies in trophic transfers, even small differences in trophic position can have a substantial effect on the amount of primary production needed to support fish production on an annual basis. For example, a simplified estimate of the basal primary production required to support bay anchovy in Chesapeake Bay can be used to examine the effect of trophic position. Using an estimate of summer bay-anchovy biomass in Chesapeake Bay $\left(\sim 23.5 \times 10^{3}\right.$ metric tons [mt]; Jung \& Houde 2004) and assuming a trophic transfer efficiency of $10 \%$ (Pauly \& Christensen 1995), the photosynthetic biomass pool required to produce the mid-summer population of bay anchovy would equate to either $16.3 \times 10^{6} \mathrm{mt}$ (shelf estimate) or $77.8 \times 10^{5} \mathrm{mt}$ (estuary estimate). While admittedly coarse, these simple calculations underscore the importance of relatively small changes in realized trophic position in constraining potential nursery production for abundant secondary consumers.

Unlike juvenile bay anchovy, bluefish trophic position was functionally equivalent despite taxonomic differences in prey composition. Piscivorous species are typically associated with a higher vertical trophic niche than invertivores, yet bluefish trophic position did not vary between shelf and estuarine habitats despite the increased importance of invertebrates in the diet of shelf fish. This is likely due to the high trophic position of the specific invertebrates consumed by juvenile shelf bluefish, particularly Loligo spp. squid. Juvenile coastal squid species are primarily zooplanktivores (Jacobson 2005) and occupy a trophic position similar to juvenile bay anchovy. This is supported by ancillary stable isotope data collected during the shelf trawl survey in which the $\delta^{15} \mathrm{~N}$ of juvenile squid $(14.80 \pm 0.38 \%$, 53 to $87 \mathrm{~mm}$ mantle length, $\mathrm{n}=2$; R. J. Woodland unpubl.) was very similar to that of juvenile bay anchovy. It is interesting to note that despite juvenile bluefish consuming juvenile bay anchovy similar in size to those analyzed for the present study (bay anchovy in the stomachs of bluefish from shelf were $35-76 \mathrm{~mm}$ in total length, and from estuary were 28-69 $\mathrm{mm}$ ), isotope evidence indicates that bluefish and bay anchovy were separated by $<1$ full trophic level (i.e. $\delta^{15} \mathrm{~N}_{\text {predator }}-\delta^{15} \mathrm{~N}_{\text {prey }}<3.4 \%$ ) regardless of habitat. This blurring of trophic separation between consumer and a primary prey species underscores the failure of discrete trophic levels to accurately represent the adaptive foraging behaviors exhibited by most fish (Gerking 1994). Mechanistically, isotopic deviations from expected isotopic predator-prey trophic separation could arise from a temporal lag in isotopic equilibrium arising from prey switching by the consumer or prey, species-specific variability in trophic fractionation of $\delta^{15} \mathrm{~N}$ (McCutchan et al. 2003), or the influence of unobserved or rare prey on integrated isotopic signatures. Similarly, the difference between dietary and isotopic estimates of trophic position could be due to a temporal lag between diet changes (e.g. ontogenetic, gape-dependent) and the equilibration of consumer tissues to the new diet, the effect of opportunistic foraging on dietbased estimates of trophic position, or (most likely) a combination of these 2 effects.

\section{Condition}

Thermal stress and hypoxia have been identified as potential factors contributing to negative, sublethal 
effects in estuarine fish species (e.g. decreased growth and condition; Eby \& Crowder 2002). If bluefish or bay-anchovy metabolism is elevated in the estuary due to chronic exposure to bioenergetically suboptimal environmental conditions (e.g. hyperthermia, hypoxia), the fraction of the total energy budget available for somatic growth is reduced (Hartman \& Brandt 1995). The subsequent reduction in energy available for storage is one potential explanation for the difference in $\mathrm{C}: \mathrm{N}$ ratio between shelf and estuarine cohorts. Alternatively, the differences in $\mathrm{C}: \mathrm{N}$ ratios could reflect the unique spectrum of prey available to bluefish and bay anchovy in each habitat. If the quantity or quality of prey varied between habitats, dissimilarities in the energetic profitability of foraging activity would be expected despite functionally (or taxonomically) similar dietary composition (e.g. Mazur et al. 2007). Such foodweb mechanisms could reasonably be expected to propagate through trophic transfers. Thus, if shelf bay anchovy are able to increase their lipid stores by gleaning greater energetic return per unit prey, then, as prey, shelf juvenile bay anchovy would yield increased lipid per unit biomass to juvenile bluefish than juvenile bay anchovy in the estuary.

Making direct comparisons between species is difficult, but it is interesting to speculate on why differences in condition between habitats were more apparent for bay anchovy than bluefish. Bay anchovy are a small, schooling species and any difference in the availability or composition of zooplankton between habitats could have a direct effect on the ability of individuals within the aggregate school to locate and exploit patches of prey. For example, Kimmel et al. (2006) showed that the zooplankton community in Chesapeake Bay is seasonally and interannually (as well as spatially) variable in terms of species composition, density, and size-structure. A spatiotemporal mismatch between the availability of appropriately sized zooplanktonic prey and juvenile bay-anchovy trophic demand in 2008 could be one reason for the lower condition observed in the estuarine cohort. Conversely, the increased mobility and wider potential prey size-spectrum (due to larger gape size; Scharf et al. 2000) of bluefish could have played a role in mitigating any differences in the availability or composition of prey between habitats.

The bimodal cohort structure of bluefish in the MAB (i.e. spring cohort typically recruits to estuaries while the summer cohort typically recruits to the shelf) confounded to an unknown extent the comparison of physiological condition between habitats. Although the separation of cohorts between habitats is not absolute (i.e. some spring-spawned bluefish occur on the shelf and vice versa), $\mathrm{C}$ and $\mathrm{N}$ data were not available from any members of these minority population components. Also, due to the lack of previously published studies that report summer lipid values for age-0 bluefish, we were unable to compare the cohort-specific $\mathrm{C}: \mathrm{N}$ lipid proxy patterns that we observed to values from the same month(s) from other regions or years. Still, it is worth noting recent work by Slater et al. (2007) and Morley et al. (2007) that found that spring and summer cohorts of age-0 bluefish manifested different energy allocation strategies by fall; members of the spring-spawned cohort entered the October-November overwintering period with higher lipid reserves than summerspawned fish that presumably shunted more energy into somatic growth. We observed the opposite pattern, i.e. that larger (spring cohort, estuary) fish showed a lower C:N lipid proxy per unit mass in August than the smaller summer-spawned bluefish from the shelf. It is unlikely that this is simply due to differences in size or age between habitats, because the higher stoichiometric lipid proxy in shelf fish was maintained when we compared the condition of shelf and estuarine bluefish of equal body-size (i.e. July estuary bluefish C:N lipid proxy < August shelf bluefish C:N lipid proxy; see Fig. 3).

There are several caveats to the present study that should be noted. First, diet and isotope sample collection was limited to the month of August; therefore, future work is needed before the observed differences in trophic niche and condition between habitats can be confidently expanded to the entire juvenile residency period of either species. Similarly, extending this type of analysis to include multiple years would provide critical perspective on the interannual consistency and variability of spatial patterns in the juvenile trophic niche of these species. Second, the Maryland coastline is punctuated by a series of lagoons-habitats that can more closely resemble estuaries in terms of salinity, temperature, depth, and nutrient loads than the adjacent inner continental shelf. Given the close proximity of coastal lagoon and shelf habitats, it is possible that individuals of either species captured on the shelf had spent an earlier component of their nursery period in a coastal lagoon. Still, the tight clustering of isotope data presented here for the shelf cohorts and indirect evidence from trawl surveys (e.g. late summer juvenile bluefish abundance $80 \%$ lower in lagoon versus shelf habitats; M. O'Brien \& D. Secor unpubl. data) support the assumption that these individuals were resident on the shelf for much of the summer growth period. 
Currently, there is very little published data on nonmigratory (i.e. feeding forays) or pre-migration staging movements of juvenile finfish between coastal lagoons and the US Atlantic inner continental shelf, and continued research is needed to resolve the spatial connectivity between these proximal nursery habitats. Finally, our use of the C:N ratio as a proxy for lipid content is predicated on the C-rich elemental composition of lipid relative to the nitrogenous protein structure of lean muscle mass (e.g. Kiljunen et al. 2006, Post et al. 2007). This relationship is the basis for mathematical C:N normalization of lipid content prior to interpretation of $\delta^{13} \mathrm{C}$ data. One potential drawback to using the $\mathrm{C}: \mathrm{N}$ ratio obtained during stable isotope analysis as an indicator of juvenile condition is that it reflects a bulk lipid estimate inclusive of all lipid classes present in the epaxial musculature (e.g. triacylglycerols, sterols). It also does not distinguish between $\mathrm{C}$ incorporated in lipids versus carbohydrates, although the latter are generally negligible in fish muscle tissues (Gnaiger \& Bitterlich 1984).

\section{CONCLUSIONS}

Overall, we found evidence that juvenile bay anchovy and bluefish can realize significant differences in trophic niche when recruiting to coastal ocean versus estuarine nursery habitats. The evidence that estuarine diets of juvenile bay anchovy and bluefish are almost exclusively composed of pelagic primary production is particularly interesting given that these species utilized both pelagic and benthic food webs in shelf habitats. In fact, the constrained niche of estuarine bay anchovy could be a factor influencing their lower body condition. By integrating information on consumed and assimilated prey, the present study highlights both the similarities (e.g. trophic position) and differences (e.g. extent of benthic vs. pelagic food web coupling) in the functional trophic niche that can arise between juvenile cohorts exploiting different habitats. As such, trophic niche indices provide a potentially valuable class of explanatory variables for examining spatially explicit juvenile production patterns.

Acknowledgements. We thank M. Fabrizio, H. Brooks, and L. Machut (Virginia Institute of Marine Science); S. Cluett and D. Bowman (State University of New York Stony Brook); and R. Wingate, K. Fenske, D. Loewensteiner, and J. Edwards (Chesapeake Biological Lab) for their aid in survey logistics and sample collection. R. Proulx provided MatLab code for convex hull analysis. E. Houde, M. Wilberg, R. Hood, M. Pal- mer, and several anonymous reviewers provided valuable feedback on an earlier version of this manuscript.

\section{LITERATURE CITED}

Able KW, Fahay MP (1998) The first year of life of estuarine fishes in the Middle Atlantic Bight. Rutgers University Press, New Brunswick, NJ

Able KW, Rowe P, Burlas M, Byrne D (2003) Use of ocean and estuarine habitats by young-of-year bluefish (Pomatomus saltatrix) in the New York Bight. Fish Bull 101: 201-214

Atkinson CL, Opsahl SP, Covich AP, Golladay SW, Conner LM (2010) Stable isotopic signatures, tissue stoichiometry, and nutrient cycling ( $\mathrm{C}$ and $\mathrm{N}$ ) of native and invasive freshwater bivalves. J N Am Benthol Soc 29:496-505

Bearhop S, Adams CE, Waldron S, Fuller RA, Macleod H (2004) Determining trophic niche width: a novel approach using stable isotope analysis. J Anim Ecol 73: 1007-1012

Beck MW, Heck KL, Able KW, Childers DL and others (2001) The identification, conservation, and management of estuarine and marine nurseries for fish and invertebrates. Bioscience 51:633-641

Buchheister A, Latour RJ (2010) Turnover and fractionation of carbon and nitrogen stable isotopes in tissues of a migratory coastal predator, summer flounder (Paralichthys dentatus). Can J Fish Aquat Sci 67:445-461

Buckel JA, Conover DO (1997) Movements, feeding periods, and daily ration of piscivorous young-of-the-year bluefish, Pomatomus saltatrix, in the Hudson River estuary. Fish Bull 95:665-679

Cabana G, Rasmussen JB (1996) Comparison of aquatic food chains using nitrogen isotopes. Proc Natl Acad Sci USA 93:10844-10847

Callihan JL, Takata LT, Woodland RJ, Secor DH (2008) Cohort splitting in bluefish, Pomatomus saltatrix, in the US mid-Atlantic Bight. Fish Oceanogr 17:191-205

> Clarke KR (1993) Nonparametric multivariate analyses of changes in community structure. Aust J Ecol 18:117-143

> Cornwell WK, Schwilk DW, Ackerly DD (2006) A trait-based test for habitat filtering: convex hull volume. Ecology 87: 1465-1471

Dahlgren CP, Kellison GT, Adams AJ, Gillanders BM and others (2006) Marine nurseries and effective juvenile habitats: concepts and applications. Mar Ecol Prog Ser 312:291-295

Douglass JG, Duffy JE, Canuel EA (2011) Food web structure in a Chesapeake Bay eelgrass bed as determined through gut contents and ${ }^{13} \mathrm{C}$ and ${ }^{15} \mathrm{~N}$ isotope analysis. Estuar Coast 34:701-711

> Eby LA, Crowder LB (2002) Hypoxia-based habitat compression in the Neuse River Estuary: context-dependent shifts in behavioral avoidance thresholds. Can J Fish Aquat Sci 59:952-965

Epifanio CE, Garvine RW (2001) Larval transport on the Atlantic continental shelf of North America: a review. Estuar Coast Shelf Sci 52:51-77

Fertig B, Carruthers TJB, Dennison WC, Fertig EJ, Altabet MA (2010) Eastern oyster (Crassostrea virginica) $\delta^{15} \mathrm{~N}$ as a bioindicator of nitrogen sources: observations and modeling. Mar Pollut Bull 60:1288-1298

Fry B (2002) Conservative mixing of stable isotopes across estuarine salinity gradients: a conceptual framework for 
monitoring watershed influences on downstream fisheries production. Estuaries 25:264-271

Gerking SD (1994) Feeding ecology of fish. Academic Press, San Diego, CA

Gibson RN (1994) Impact of habitat quality and quantity on the recruitment of juvenile flatfishes. Neth J Sea Res 32: 191-206

- Gnaiger E, Bitterlich G (1984) Proximate biochemical composition and caloric content calculated from elemental CHN analysis: a stoichiometric concept. Oecologia 62: 289-298

> Graeve M, Kattner G, Piepenburg D (1997) Lipids in Arctic benthos: Does the fatty acid and alcohol composition reflect feeding and trophic interactions? Polar Biol 18: $53-61$

> Hartman KJ, Brandt SB (1995) Comparative energetics and the development of bioenergetics models for sympatric estuarine piscivores. Can J Fish Aquat Sci 52:1647-1666

Herzka SZ (2005) Assessing connectivity of estuarine fishes based on stable isotope ratio analysis. Estuar Coast Shelf Sci 64:58-69

Hesslein RH, Hallard KA, Ramlal P (1993) Replacement of sulfur, carbon, and nitrogen in tissue of growing broad whitefish (Coregonus nasus) in response to a change in diet traced by $\delta^{34} \mathrm{~S}, \delta^{13} \mathrm{C}$, and $\delta^{15} \mathrm{~N}$. Can J Fish Aquat Sci 50:2071-2076 doi:10.1139/f93-230

> Hyslop EJ (1980) Stomach contents analysis-a review of methods and their application. J Fish Biol 17:411-429

Jacobson LD (2005) Longfin inshore squid, Loligo pealeii, life history and habitat characteristics. Essential Fish Habitat Source Document, NOAA Tech Memo NMFSNE-193. Northeast Fisheries Science Center, Woods Hole, MA

Jung S, Houde ED (2004) Recruitment and spawning-stock biomass distribution of bay anchovy (Anchoa mitchilli) in Chesapeake Bay. Fish Bull 102:63-77

Kendall AW, Walford LA (1979) Sources and distributions of bluefish, Pomatomus saltatrix, larvae and juveniles off the east coast of the United States. Fish Bull 77: 213-227

Kiljunen M, Grey J, Sinisalo T, Harrod C, Immonen H, Jones RI (2006) A revised model for lipid-normalizing $\delta^{13} \mathrm{C}$ values from aquatic organisms, with implications for isotope mixing models. J Appl Ecol 43:1213-1222

Kimmel DG, Roman MR, Zhang X (2006) Spatial and temporal variability in factors affecting mesozooplankton dynamics in Chesapeake Bay: evidence from biomass size spectra. Limnol Oceanogr 51:131-141

Kimura R, Secor DH, Houde ED, Piccoli PM (2000) Upestuary dispersal of young-of-the-year bay anchovy Anchoa mitchilli in the Chesapeake Bay: inferences from microprobe analysis of strontium in otoliths. Mar Ecol Prog Ser 208:217-227

Kovalenko KE, Dibble ED (2011) Effects of invasive macrophyte on trophic diversity and position of secondary consumers. Hydrobiologia 663:167-173

Kraus RT, Secor DH (2005) Application of the nursery-role hypothesis to an estuarine fish. Mar Ecol Prog Ser 291: 301-305

> Layman CA, Arrington DA, Montana CG, Post DM (2007) Can stable isotope ratios provide for community-wide measures of trophic structure? Ecology 88:42-48

Long WC, Seitz RD (2009) Hypoxia in Chesapeake Bay tributaries: worsening effects on macrobenthic community structure in the York River. Estuar Coast 32:287-297
Ludsin SA, Zhang X, Brandt SB, Roman MR, Boicourt WC, Mason DM, Costantini M (2009) Hypoxia-avoidance by planktivorous fish in Chesapeake Bay: implications for food web interactions and fish recruitment. J Exp Mar Biol Ecol 381(Suppl 1):S121-S131

Mazur MM, Wilson MT, Dougherty AB, Buchheister A, Beauchamp DA (2007) Temperature and prey quality effects on growth of juvenile walleye pollock Theragra chalcogramma (Pallas): a spatially explicit bioenergetics approach. J Fish Biol 70:816-836

McConnaughey T, McRoy CP (1979) Food-web structure and the fractionation of carbon isotopes in the Bering Sea. Mar Biol 53:257-262

McCutchan JH, Lewis WM, Kendall C, McGrath CC (2003) Variation in trophic shift for stable isotope ratios of carbon, nitrogen, and sulfur. Oikos 102:378-390

> Morley JW, Buckel JA, Lankford TE (2007) Winter energy storage dynamics and cohort structure of young-of-theyear bluefish Pomatomus saltatrix off North Carolina. Mar Ecol Prog Ser 334:273-286

Morton RM, Halliday I, Cameron D (1993) Movement of tagged juvenile tailor (Pomatomus saltatrix) in Moreton Bay, Queensland. Aust J Mar Freshw Res 44:811-816

Nislow KH, Folt CL, Parrish DL (2000) Spatially explicit bioenergetic analysis of habitat quality for age-0 Atlantic salmon. Trans Am Fish Soc 129:1067-1081

Pauly D, Christensen V (1995) Primary production required to sustain global fisheries. Nature 374:255-257

Peterson BJ, Fry B (1987) Stable isotopes in ecosystem studies. Annu Rev Ecol Syst 18:293-320

Post DM (2002) Using stable isotopes to estimate trophic position: models, methods, and assumptions. Ecology 83: 703-718

Post DM, Layman CA, Arrington DA, Takimoto G, Quattrochi J, Montana CG (2007) Getting to the fat of the matter: models, methods and assumptions for dealing with lipids in stable isotope analyses. Oecologia 152: 179-189

Quevedo M, Svanbäck R, Eklöv P (2009) Intrapopulation niche partitioning in a generalist predator limits food web connectivity. Ecology 90:2263-2274

Raymond PA, Bauer JE (2001) Use of ${ }^{14} \mathrm{C}$ and ${ }^{13} \mathrm{C}$ natural abundances for evaluating riverine, estuarine, and coastal DOC and POC sources and cycling: a review and synthesis. Org Geochem 32:469-485

Rosenfeld JS, Leiter T, Lindner G, Rothman L (2005) Food abundance and fish density alters habitat selection, growth, and habitat suitability curves for juvenile coho salmon (Oncorhynchus kisutch). Can J Fish Aquat Sci 62: 1691-1701

Scharf FS, Juanes F, Rountree RA (2000) Predator size-prey size relationships of marine fish predators: interspecific variation and effects of ontogeny and body size on trophic-niche breadth. Mar Ecol Prog Ser 208:229-248

> Schultz ET, Conover DO (1997) Latitudinal differences in somatic energy storage: adaptive responses to seasonality in an estuarine fish (Atherinidae: Menidia menidia). Oecologia 109:516-529

Secor DH (2007) The year-class phenomenon and the storage effect in marine fishes. J Sea Res 57:91-103

> Sheaves M, Baker R, Johnston R (2006) Marine nurseries and effective juvenile habitats: an alternative view. Mar Ecol Prog Ser 318:303-306

Shumway SE (1996) Natural environmental factors. In: Kennedy VS, Newell RIE, Eble AF (eds) The eastern oys- 
ter, Crassostrea virginica. Maryland Sea Grant College, University of Maryland, College Park, MD, p 467-513

Slater JJ, Lankford TE, Buckel JA (2007) Overwintering ability of young-of-the-year bluefish Pomatomus saltatrix: effect of ration and cohort of origin on survival. Mar Ecol Prog Ser 339:259-269

Tuckey TD, Fabrizio MC (2009) Estimating relative juvenile abundance of ecologically important finfish in the Virginia portion of Chesapeake Bay. Virginia Institute of Marine Science, Gloucester Point, VA

Werner EE, Gilliam JF (1984) The ontogenetic niche and species interactions in size-structured populations. Annu Rev Ecol Syst 15:393-425

Editorial responsibility: Matthias Seaman, Oldendorf/Luhe, Germany
Winemiller KO, Akin S, Zeug SC (2007) Production sources and food web structure of a temperate tidal estuary: integration of dietary and stable isotope data. Mar Ecol Prog Ser 343:63-76

Woodland RJ, Secor DH, Wedge ME (2011) Trophic resource overlap between small elasmobranchs and sympatric teleosts in Mid-Atlantic Bight nearshore habitats. Estuar Coast 34:391-404

Zambrano L, Valiente E, Vander Zanden MJ (2010) Food web overlap among native axolotl (Ambystoma mexicanum) and two exotic fishes: carp (Cyprinus carpio) and tilapia (Oreochromis niloticus) in Xochimilco, Mexico City. Biol Invasions 12:3061-3069

Submitted: November 15, 2010; Accepted: July 21, 2011

Proofs received from author(s): October 3, 2011 